Molecular pathology

\title{
Translating research into cancer molecular diagnostics and patents
}

M Ladanyi

\section{Revisiting a key paper in diagnostic molecular haematopathology to mark 60 years of $J C P$}

n terms of the Diamond Jubilee celebration of the Journal of Clinical Pathology (JCP), it is evident that molecular pathology is still a relatively young field. Thus, one of the most notable papers published in the journal in this area appeared not 60 years ago, but only 15 years ago. In November 1990, in an article entitled "Monoclonality in B cell lymphoma detected in paraffin wax embedded sections using the polymerase chain reaction", Alec Morley's group described the application of the polymerase chain reaction (PCR) to detect $\mathrm{B}$ cell monoclonality in formalin fixed, paraffin wax embedded material. ${ }^{1}$ This was based on the use of consensus primers for the variable and joining regions of the IGH (immunoglobulin heavy chain) gene, as illustrated in figure 1 of that paper, which has been reproduced here (fig 1). The sensitivity of the approach was documented by positive PCR results in 24 of 26 B cell lymphomas, and its specificity was established by the negative results obtained in 28 other samples. The authors concluded that: "this technique is likely to be of value in routine diagnosis, because of its speed, simplicity, and applicability to fixed, embedded material". This has proved to be an understatement, because some form of this method has been adopted by almost all molecular haematopathology laboratories throughout the world. As one of the most highly cited papers to appear in $J C P$, it has been referenced over 280 times since publication. It was preceded by two papers in other journals reporting the general development of PCR based detection of clonal rearrangements of the IGH gene, ${ }^{23}$ and it was followed by several articles describing refinements or new applications of the methods. ${ }^{4-6}$ At about the same time, several other groups also reported similar PCR based assays using consensus primers for the variable and joining regions of the $\mathrm{IGH}^{7}{ }^{8}$ or TCRG ( $\mathrm{T}$ cell receptor $\gamma$ chain) genes. ${ }^{9}$

Although the initial descriptions of PCR based testing of clonal rearrangements of the IGH and TCRG genes relied on conventional electrophoresis in ethidium bromide stained gels to distinguish monoclonal from polyclonal PCR products, the advent of capillary electrophoresis methods coupled with fluorescent detection allowed much less subjective interpretation of the results, further broadening the appeal of PCR over Southern blotting in this molecular diagnostic setting. ${ }^{10}$ The development of these methods culminated recently in the BIOMED-2 collaborative study, which led to new optimised primer combinations for the detection of IGH and TCR gene rearrangements. ${ }^{11}$ The paper by Morley and coworkers in JCP is an early example of what has come to be known as translational research. In this case, the knowledge gained from sequencing the human antigen receptor genes and understanding their sequential physiological rearrangement events and their combinatorial diversity was used to develop a practical diagnostic assay.

In parallel with these landmark papers in JCP and other journals, Alec Morley and Michael Brisco filed a US patent application in October 1989 that was granted on 22 March 1994 (US patent number 5296351 and continuation patent number 5418 134). Patents were also filed in Australia and Japan

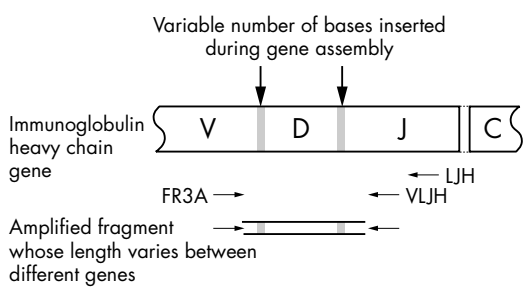

Figure 1 Diagram to show the human IGH gene and the location of the primers for the seminested polymerase chain reaction: Fr3A, $\mathrm{LH}$, and $\mathrm{VLH}$, and the sites where various numbers of nucleotides are added at random during $B$ cell differentiation. $V, D, J$, and $C$ represent the variable, diversity, joining, and constant segments of the gene (adapted from Wan and colleagues').
(Australian patent number 626601 , Japanese patent number 2781 438). Even as PCR based testing of clonal rearrangements of IGH and TCRG became commonplace in molecular diagnostic laboratories, little notice was paid to these patents and they were not enforced. This changed in 2002 when the patents were licensed exclusively to InVivoScribe. The patents are currently enforced in the USA, Australia, and Japan, where sublicences are required for PCR testing of the IGH and TCRG loci. Testing done for teaching and basic research is not subject to licensing fees or royalties but does require registering with the company. All other testing requires paying for a sublicence to these patents and making royalty payments from I January 2003 (or retroactively from that date). Royalty payments are lower for laboratories that exclusively use the InVivoScribe kits for the PCR testing of the IGH and TCRG loci. Thus, the work reported in this paper and its later history illustrate not only the promise of translational research but also the issues raised by the patenting and licensing of genomic inventions.

"It has been argued that costly royalty bearing licensing can limit or deter the use of specific molecular tests by molecular diagnostic laboratories in not for profit academic hospitals"

The impact of gene patents on the practice of molecular diagnostics has been studied and discussed extensively. ${ }^{12-15}$ Although the most negative effects have been in situations where exclusive licence enforcement has been used to centralise testing ( so far only for some hereditary disease testing), in cases such as the present one, it has been argued that costly royalty bearing licensing can limit or deter the use of specific molecular tests by molecular diagnostic laboratories in not for profit academic hospitals because of tight budgets and/or poor reimbursement of molecular diagnostic assays. That the research leading to many of these somatic or germline genetic tests was publicly funded is another vexing aspect of the situation. The Association for Molecular Pathology has recently issued an official comment on patenting issues as they affect the practice of molecular diagnostics (www.ampweb.org/PRC/ GenomicInventions.doc). In any case, these issues will cease to apply to PCR testing of the IGH and TCRG loci in six years, when the above patents will expire (the US patent expires on 22 March 2011). However, this complex issue will probably become even more important over the coming years, as 
more and more molecular diagnostic assays become widely used. For instance, Genzyme Corporation recently announced that it had acquired exclusive worldwide diagnostic rights to the testing of EGFR (epidermal growth factor receptor gene) mutations found in some adenocarcinomas of the lung that predict response to certain EGFR inhibitors (www.genzyme.com/corp/ investors/GENZ\%20PR-050205.asp). ${ }^{16-18}$ How this exclusive licence for EGFR testing will be enforced is unknown at this time, but it highlights how the issues raised by the history of this landmark paper on IGH PCR testing in JCP remain relevant to the area of cancer molecular diagnostics, at the same time as it exemplifies early translational research in this field.

\section{ACKNOWLEDGEMENTS}

Thanks to Dr V Martin for help with the interpretation of patent documents.

J Clin Pathol 2005;58:793-794. doi: 10.1136/jcp.2005.030668

Correspondence to: Dr M Ladanyi, Department of Pathology, Memorial Sloan-Kettering Cancer Center, 1275 York Avenue, New York, NY 10021, USA; ladanyim@mskcc.org

\section{REFERENCES}

1 Wan JH, Trainor KJ, Brisco MJ, et al. Monoclonality in B cell lymphoma detected in paraffin wax embedded sections using the polymerase chain reaction. J Clin Pathol 1990;43:888-90.

2 Trainor KJ, Brisco MJ, Story CJ, et al. Monoclonality in B-lymphoproliferative disorders detected at the DNA level. Blood 1990:75:2220-2.

3 Brisco MJ, Tan LW, Orsborn AM, et al. Development of a highly sensitive assay, based on the polymerase chain reaction, for rare Blymphocyte clones in a polyclonal population. BrJ Haematol 1990;75:163-7.

4 Wan JH, Sykes PJ, Orell SR, et al. Rapid method for detecting monoclonality in B cell lymphoma in lymph node aspirates using the polymerase chain reaction. J Clin Pathol 1992;45:420-3.

5 Ramasamy I, Brisco M, Morley A. Improved PCR method for detecting monoclonal immunoglobulin heavy chain rearrangement in B cell neoplasms. $J$ Clin Pathol 1992:45:770-5.

6 Trainor KJ, Brisco MJ, Wan JH, et al. Gene rearrangement in $\mathrm{B}$ - and T-lymphoproliferative disease detected by the polymerase chain reaction. Blood 1991;78:192-6.

7 McCarthy KP, Sloane JP, Wiedemann LM. Rapid method for distinguishing clonal from polyclonal $B$ cell populations in surgical biopsy specimens. J Clin Pathol 1990;43:429-32.

8 Deane M, Norton JD. Detection of immunoglobulin gene rearrangement in $B$ lymphoid malignancies by polymerase chain reaction gene amplification. $\mathrm{Br} J$ Haematol 1990;74:251-6.

9 Bourguin A, Tung R, Galili N, et al. Rapid, nonradioactive detection of clonal T-cell receptor gene rearrangements in lymphoid neoplasms. Proc Natl Acad Sci U S A 1990;87:8536-40.
10 Beaubier NT, Hart AP, Bartolo C, et al. Comparison of capillary electrophoresis and polyacrylamide gel electrophoresis for the evaluation of $T$ and $B$ cell clonality by polymerase chain reaction. Diagn Mol Pathol 2000;9:121-31.

11 van Dongen JJ, Langerak AW, Bruggemann $M$, et al. Design and standardization of PCR primers and protocols for detection of clonal immunoglobulin and T-cell receptor gene recombinations in suspect lymphoproliferations: report of the BIOMED-2 concerted action BMH4-CT98-3936. Leukemia 2003;17:2257-317.

12 Merz JF. Disease gene patents: overcoming unethical constraints on clinical laboratory medicine. Clin Chem 1999:45:324-30.

13 Merz JF, Kriss AG, Leonard DG, et al. Diagnostic testing fails the test. Nature 2002;415:577-9.

14 Leonard DG. Medical practice and gene patents: a personal perspective. Acad Med 2002;77:1388-91.

15 Cho MK, Illangasekare S, Weaver MA, et al. Effects of patents and licenses on the provision of clinical genetic testing services. J Mol Diagn 2003;5:3-8

16 Lynch TJ, Bell DW, Sordella R, et al. Activating mutations in the epidermal growth factor receptor underlying responsiveness of non-small-cell lung cancer to gefitinib. N Engl J Med 2004;350:2129-39.

17 Paez JG, Janne PA, Lee JC, et al. EGFR mutations in lung cancer: correlation with clinical response to gefitinib therapy. Science 2004;304: 1497-500

18 Pao W, Miller V, Zakowski MF, et al. EGF receptor gene mutations are common in lung cancers from "never smokers" and correlate with sensitivity of tumors to gefitinib (Iressa ${ }^{\circledR}$ ) and erlotinib (Tarceva ${ }^{T M}$ ). Proc Natl Acad Sci U S A 2004;101:13306-11. 